\title{
REMOVAL OF COPPER FROM WATER USING COLUMNS EXPERIMENT OF LIGNITE, SHALE, AND IRONSAND
}

\author{
Ty Boreborey, Wahyu Wilopo, and Doni Prakasa Eka Putra \\ Department of Geological Engineering, Gadjah Mada University, Yogyakarta, Indonesia
}

\begin{abstract}
Experimental studies using column testing of lignite, shale, and ironsand in copper solution were carried out to determine the adsorption capacity of lignite, shale, and ironsand in remediation of water contaminated with copper. Lignite, shale, and ironsand were analyzed using XRD, SEM/EDX, and $X R F$. The treatment process by column adsorption was carried out over a period of 24 hours at a stable velocity of $0.005 \mathrm{ml} / \mathrm{s}$. After treatment, the remaining copper in the solution was recorded, thus allowing the adsorption capacity of lignite, shale, and ironsand to be calculated. The results revealed that when the solution was treated by lignite and shale there was a good degree of copper removal, while the ironsand had very poor degree of copper removal. The best material for copper removal was lignite with 25-mesh grain size. Pyrite, graphite, calcite, and illite were found in lignite and smectite, calcite, pyrite, hematite, and illite were found in shale. These materials were also shown to contain an abundance of high-valence elements in $\mathrm{Al}_{2} \mathrm{O}_{3}$, $\mathrm{SiO}_{2}$, and $\mathrm{Fe}_{3} \mathrm{O}_{4}$ which contributes to additional adsorption capacity. CAC values for lignite and shale reached nearly to $100 \%$, suggesting that lignite and shale have a high adsorption capacity. In contrast, ironsand, which has mostly sand minerals with little clay and organic content, caused the pollutant to move rapidly to the water table, reducing the adsorption potential. CAC values treated by ironsand were
\end{abstract}

${ }^{*}$ Corresponding author: T. BOREBOREY, Department of Geological Engineering, Faculty of Engineering, Gadjah Mada University, Jl. Grafika 2 Yogyakarta, 55281, Indonesia. E-mail: ty.boreborey2@gmail.com shown to be negative which showed an increasing of $\mathrm{Cu}^{2+}$ in natural ironsand into solution.

Keywords: Copper, ironsand, shale, lignite, column experiment

\section{Introduction}

Introduction Water can be contaminated by heavy metals which include copper derived from various sources. Heavy metal contamination of groundwater is a widespread problem in Indonesia. The primary sources of copper in industrial wastewaters are metal-process pickling baths and plating baths. In general, copper is soluble and bio available at low $\mathrm{pH}$ and therefore toxicity problems are likely to be more severe in acid environments (Allowey and Ayres, 1993). Many techniques have been proposed for removing contaminants from water, although most of them suffer from particular technical and economic limitations (Batchelor et al, 2002). Column and bach tests have been carried out on groundwater with known contamination levels of metals in laboratory conditions using variable concentrations of contaminants and reactive materials (Freethey et al, 2002).

The objective of this research was to characterize the lignite, shale and ironsand in terms of mineralogy, chemical composition, and physical properties in their initial conditions. Through their characteristic we also want to know the cation adsorption capacity of lignite, shale and ironsand and to identify the most effective adsorbent materials between 


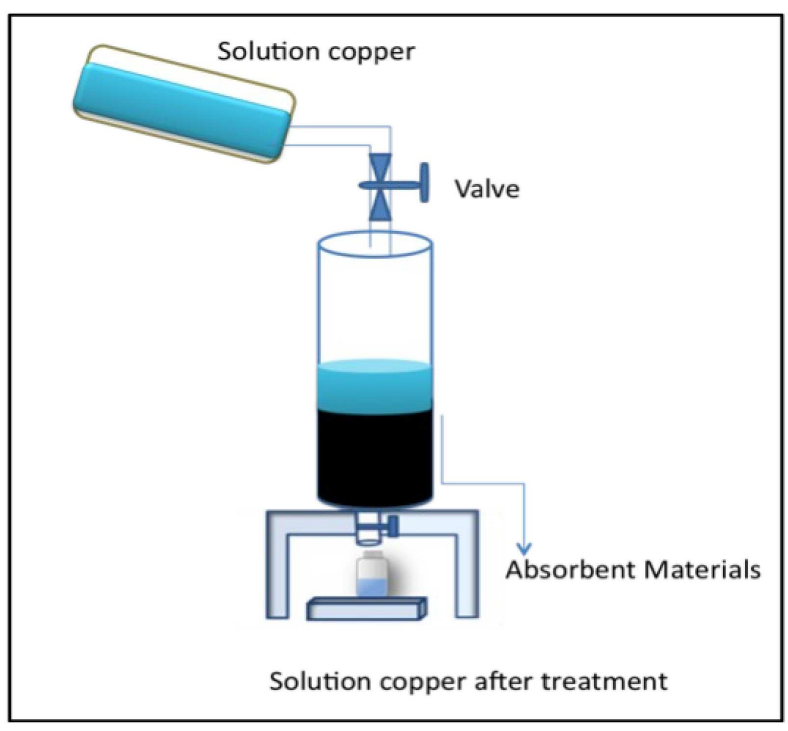

Figure 1: Schematic diagram of the experimental set up for the adsorption process.

lignite, shale and ironsand in removing copper ions from the water.

\section{Materials and Methods}

The goal of laboratory work was to determine the characteristics of the adsorption materials in terms of physical, mineralogical, and chemical properties. The lignite sample was taken from Samigaluh Kulon Progo, the shale from Bogor, and the ironsand from Glagah beach. These three materials were first characterized by means of X-ray diffraction (XRD) investigation, scanning electron microscope or energy dispersive X-ray (SEM/EDX), X-ray Fluorescence (XRF) and physical property analysis. Secondly, the column adsorption experiments were conducted over a period of 24 hours. A total of 6 columns were used with $6 \mathrm{~cm}$ diameters and heights of $30 \mathrm{~cm}$ each. Two different sizes of grains were chosen for each sample, which were coarse 10-mesh and fine 25-mesh and prepared in $300 \mathrm{~g}$ samples for each material. The 6 samples were then put into different columns as the reactive media. The solution of copper was allowed to flow vertically through the column at a constant velocity of $0.005 \mathrm{ml} / \mathrm{s}$ (Figure 1).

The experiment on groundwater treatment using lignite, shale, and ironsand with the method of column adsorption was done by putting the $300 \mathrm{~g}$ of ironsand, lignite and shale samples of 10-mesh and 25-mesh each into PVC columns, then flowing vertically the solution of copper with the concentrations of $7 \mathrm{ppm}$ into the columns. The amount of the dry ironsand, lignite and shale grains requires only one experiment each with the two different grain sizes done simultaneously over 24 hours, which is considered enough to achieve equilibrium conditions at constant temperature $\left(25^{\circ} \mathrm{C}\right)$. This is to keep the materials in suspension and allow the ion exchange reaction between the cations of ironsand, lignite and shale with the $\mathrm{Cu}^{2+}$ in solution. After the experiment, all the solutions were analyzed by the AAS (atomic absorption spectrometer) method to identify the remaining copper. The formula of Vega et al (2005) to calculate the cation adsorption capacity (CAC) or the concentrations of heavy metals adsorbed by the ironsand, lignite and shale granular is expressed below:

$$
C A C=\frac{C_{i}-C_{f}}{C_{i}} \text { or } C_{\text {ads }}=C_{i}-C_{f}
$$

Where:

$C A C$ : cation adsorption capacity (percentage adsorption)

$C_{\text {ads }}$ : concentration of heavy metal adsorbed by iron sand, lignite, and shale

$C_{i}$ : initial concentration of heavy metal (before the experiment)

$C_{f}$ : final concentration of heavy metal (after the experiment).

Figure 1: Schematic diagram of the experimental set up for the adsorption process

\section{Results and Discussion}

\subsection{Lignite}

The XRD and XRF analysis of the lignite sample indicates that the sample contains several abundant mineral types such as pyrite, graphite, and calcite (Figure 2, Table 1). The presence of graphite reveals that lignite contains organic matter that plays an important role in the adsorption mechanism. Meanwhile the presence of pyrite, calcite, tourmaline, and some clay 


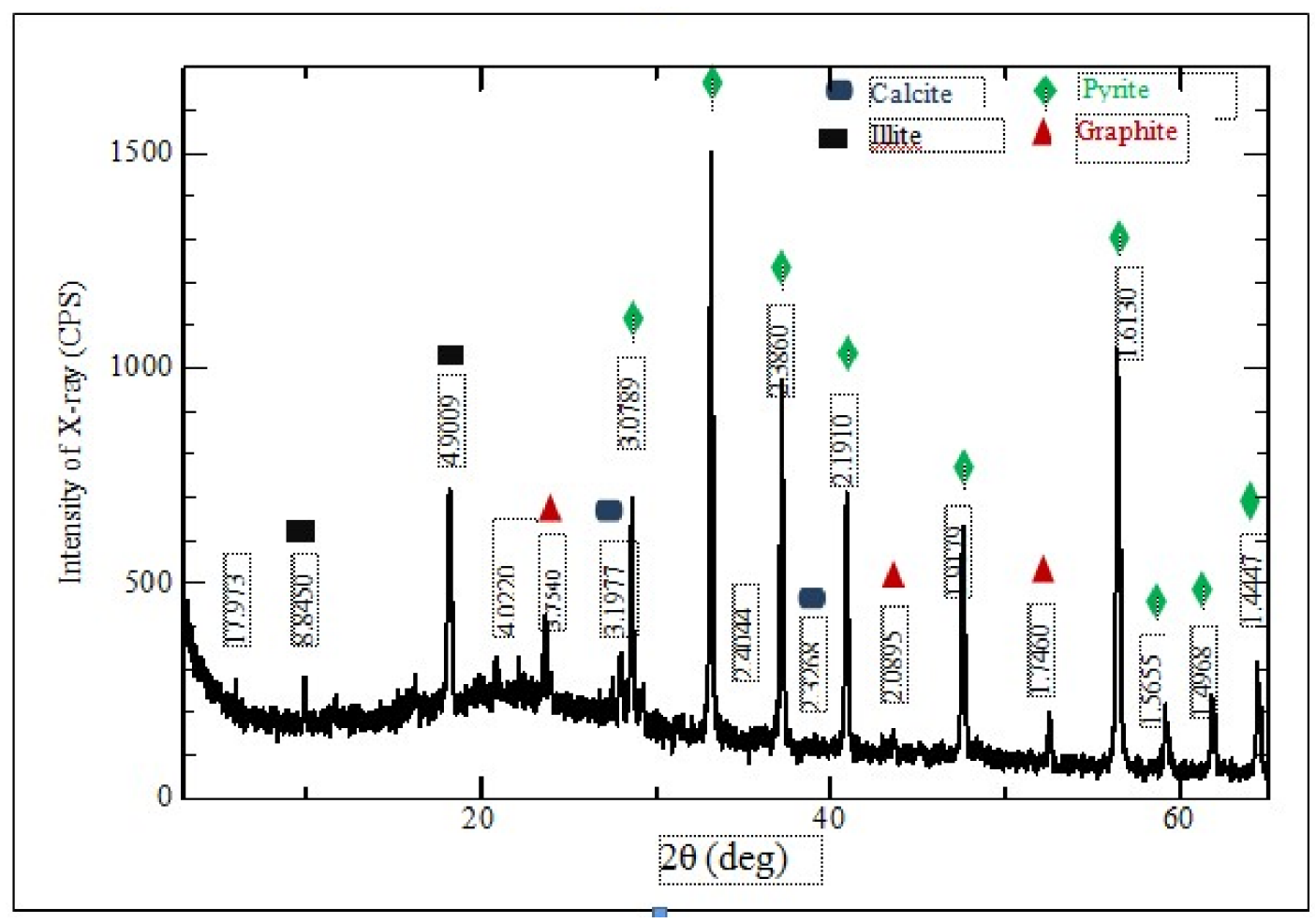

Figure 2: X-ray diffractogram of the lignite sample.

Table 1: The result of specific major oxides and trace metals for this research from XRF analysis of lignite.

\begin{tabular}{|c|c|c|c|}
\hline Elements & $\begin{array}{c}\text { Amount } \\
\text { of Lignite } \\
\text { (\%) }\end{array}$ & Oxides & $\begin{array}{c}\text { Amount } \\
\text { of Lignite } \\
\text { (\%) }\end{array}$ \\
\hline $\mathrm{Cu}$ & $<0.002$ & $\mathrm{CaO}$ & 8.17 \\
\hline $\mathrm{Pb}$ & $<0.002$ & $\mathrm{P}_{2} \mathrm{O}_{5}$ & 0.18 \\
\hline $\mathrm{Fe}$ & 7.63 & $\mathrm{SiO}_{2}$ & 49.23 \\
\hline $\mathrm{S}$ & $<0.002$ & $\mathrm{Al}_{2} \mathrm{O}_{3}$ & 21.81 \\
\hline $\mathrm{As}$ & 0.003 & $\mathrm{Fe}_{2} \mathrm{O}_{3}$ & 10.91 \\
\hline $\mathrm{Sn}$ & $<0.002$ & $\mathrm{~K}_{2} \mathrm{O}$ & 0.85 \\
\hline $\mathrm{Cl}$ & $<0.005$ & $\mathrm{TiO}_{2}$ & 1.02 \\
\hline $\mathrm{Zn}$ & 0.009 & & \\
\hline
\end{tabular}

mineral also contribute to an overall high adsorption capacity.

Using the weights of oxides present in the lignite sample, it may be interpreted that the presence of $\mathrm{Fe}_{2} \mathrm{O}_{3}$ rose to 10.91, meaning some copper was co-precipitated in this oxide and some was absorbed by $\mathrm{Al}_{2} \mathrm{O}_{3}$ and $\mathrm{SiO}_{2}$ which also have abundant weights in lignite.

\subsection{Shale}

XRD analysis of the shale samples display the major contents of smectite and calcite shown at the peaks of the diffractogram (Figure 3). Moreover, illite, hematite, and pyrite are also present in the content.

The XRF analysis showed the specific major oxides and trace metals of shale which included $\mathrm{SiO}_{2}, \mathrm{Al}_{2} \mathrm{O}_{3}, \mathrm{Na}_{2} \mathrm{O}, \mathrm{CaO}, \mathrm{K}_{2} \mathrm{O}, \mathrm{TiO}_{2}, \mathrm{Cd}, \mathrm{Cu}, \mathrm{Fe}$, $\mathrm{Pb}, \mathrm{Zn}, \mathrm{Mn}$, and $\mathrm{Ag}$ (Table 2). We can see $\mathrm{Fe}_{2} \mathrm{O}_{3}$, $\mathrm{SiO}_{2}$, and $\mathrm{Al}_{2} \mathrm{O}_{3}$ are much more abundant than other chemicals. This means the shale, like lignite, is suitable as an ion adsorption material.

\subsection{Ironsand}

From the XRD analysis of ironsand sample, we can see some major contents of magnetite, olivine, quartz, calcite, and albite show at the peaks of the diffractogram (Figure 4). This material was show to lack clay and organic matter so we could interpret which would suggest in 


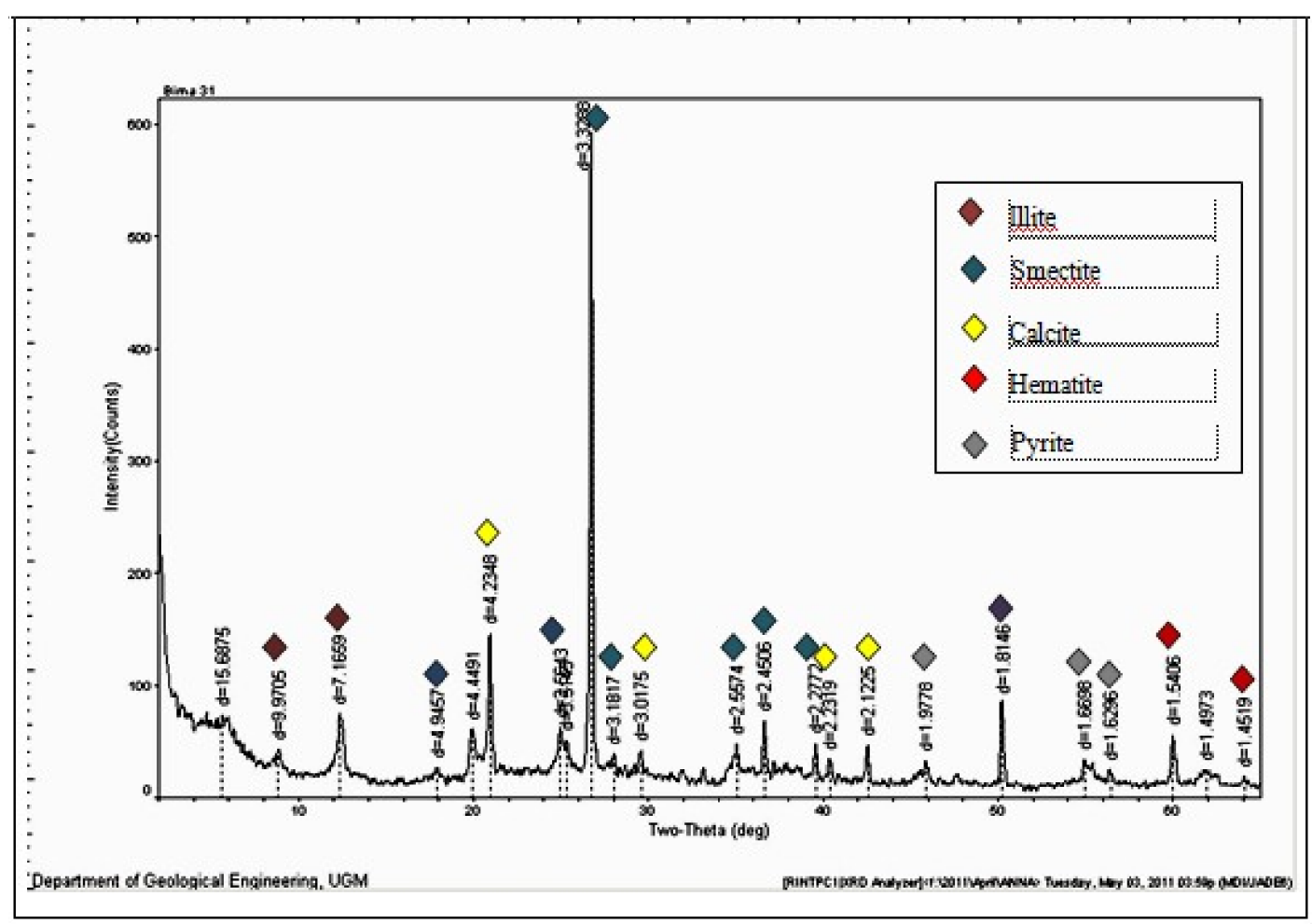

Figure 3: X-ray diffractogram of the shale.

Table 2: The result of specific major oxides and trace metals from the XRF analysis of shale.

\begin{tabular}{|l|c|l|c|}
\hline Elements & $\begin{array}{c}\text { Conc. } \\
\text { (wt.\%) }\end{array}$ & Oxides & $\begin{array}{c}\text { Conc. } \\
\text { (wt.\%) }\end{array}$ \\
\hline $\mathrm{Na}$ & 0.17 & $\mathrm{Na}_{2} \mathrm{O}$ & 0.14296 \\
\hline $\mathrm{Mg}$ & 1.509 & $\mathrm{MgO}$ & 1.216 \\
\hline $\mathrm{Al}$ & 10.56 & $\mathrm{Al}_{2} \mathrm{O}_{3}$ & 9.64 \\
\hline $\mathrm{Si}$ & 30.88 & $\mathrm{SiO}_{2}$ & 31.99 \\
\hline $\mathrm{P}$ & 0.02261 & $\mathrm{P}_{2} \mathrm{O}_{5}$ & 0.025 \\
\hline $\mathrm{K}$ & 1.79 & $\mathrm{~K}_{2} \mathrm{O}$ & 1.043 \\
\hline $\mathrm{Ca}$ & 1.433 & $\mathrm{CaO}$ & 0.97 \\
\hline $\mathrm{Ti}$ & 0.5381 & $\mathrm{TiO}_{2}$ & 0.301 \\
\hline $\mathrm{Fe}$ & 4.136 & $\mathrm{Fe}_{2} \mathrm{O}_{3}$ & 2.86 \\
\hline $\mathrm{Mn}$ & 0.0327 & $\mathrm{MnO}_{2}$ & 0.025 \\
\hline $\mathrm{Cu}$ & 0.00105 & & \\
\hline
\end{tabular}

Table 3: The result of specific major oxides and trace metals from XRF analysis of ironsand.

\begin{tabular}{|l|c|l|c|}
\hline Elements & $\begin{array}{c}\text { Conc. } \\
\text { (wt.\%) }\end{array}$ & Elements & $\begin{array}{c}\text { Conc. } \\
\text { (wt.\%) }\end{array}$ \\
\hline $\mathrm{Na}$ & 0.717 & $\mathrm{Na}_{2} \mathrm{O}$ & 0.349793 \\
\hline $\mathrm{Mg}$ & 4.281 & $\mathrm{MgO}$ & 2.582567 \\
\hline $\mathrm{Al}$ & 4.147 & $\mathrm{Al}_{2} \mathrm{O}_{3}$ & 2.835294 \\
\hline $\mathrm{Si}$ & 18.12 & $\mathrm{SiO}_{2}$ & 14.0543 \\
\hline $\mathrm{K}$ & 0.4891 & $\mathrm{~K}_{2} \mathrm{O}$ & 0.213348 \\
\hline $\mathrm{Ca}$ & 7.23 & $\mathrm{CaO}$ & 3.663735 \\
\hline $\mathrm{Ti}$ & 2.429 & $\mathrm{TiO}_{2}$ & 1.017108 \\
\hline $\mathrm{Mn}$ & 0.3986 & $\mathrm{MnO}_{2}$ & 0.216414 \\
\hline $\mathrm{Fe}$ & 25.24 & $\mathrm{Fe}_{2} \mathrm{O}_{3}$ & 13.05116 \\
\hline $\mathrm{Cu}$ & 0.00259 & & \\
\hline
\end{tabular}

theory that it would have a low adsorption capacity. The XRF analysis shows the major element oxides in the sample (Table 3).

\subsection{Solution Copper Treatment}

To know the adsorption capacity of the lignite, shale, and ironsand samples for treating copper, a study of physical and chemical characteristics was done. This study included $\mathrm{pH}$, grain 


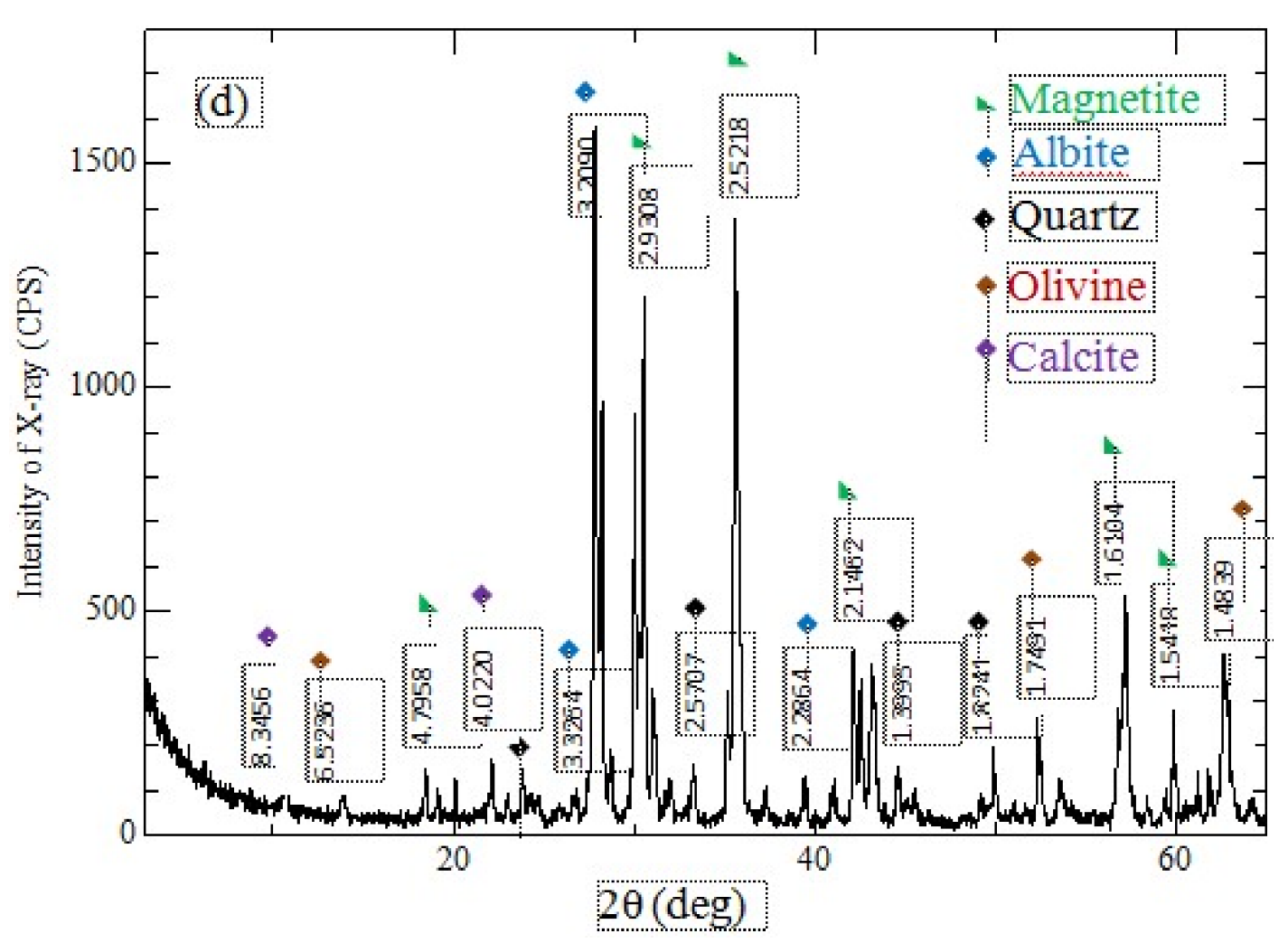

Figure 4: X-ray diffractogram of the ironsand.

size, crystal structure and chemical composition analysis. Experimental data from copper solutions from XRD and XRF analysis show that $\mathrm{Cu}^{2+}$ was removed by shale and lignite more than ironsand. The negative values from ironsand suggest that it is not suitable for the treatment copper whatsoever.

According to Figure 5, the CAC of shale of grain size 25 -mesh is nearly $100 \%$ from the beginning of treatment at the duration of 20 hours at which point CAC began to drop. The CAC of shale with grain size 10-mesh decreased at the duration 18-24 hours. Lignite however strongly absorbed $\mathrm{Cu}^{2+}$ over the entire period of treatment with no apparent decreasing of CAC even at the duration of 24 hours. Ironsand displayed negative values for $\mathrm{CAC}$, and it can thus be said that it has no capacity in copper removal and may even more cause the content of $\mathrm{Cu}^{2+}$ in solution to increase.

\section{Conclusion}

The absorption capacities of lignite, shale and ironsand have been characterized. For lignite, XRD showed that clay minerals and the organic matter were abundant and XRF showed abundant weights for the elements and oxides $\mathrm{C}$, $\mathrm{Al}, \mathrm{Si}, \mathrm{Fe}, \mathrm{Al}_{2} \mathrm{O}_{3}, \mathrm{SiO}_{2}$, and $\mathrm{Fe}_{3} \mathrm{O}_{4}$. In comparison, shale contained no organic content, but more clay minerals were detected. XRF analyses showed abundant weight for the elements and oxides $\mathrm{Al}, \mathrm{Si}, \mathrm{Fe}, \mathrm{Al}_{2} \mathrm{O}_{3}$, and $\mathrm{SiO}_{2}$. These parameters play an important role in the degree of overall adsorption. In contrast with lignite and shale, ironsand analysis showed abundant magnetite, olivine, quartz, and calcite and a lack of clay and organic matter. This is thought to cause ironsand to have a low absorption capacity and cause the pollutant move rapidly to the water table, reducing the effectiveness of the adsorption process.

When the copper solution was treated by lignite, $\mathrm{Cu}^{2+}$ became insoluble in the solution due to $\mathrm{pH}$ increasing from acidity to neutral and $\mathrm{Cu}^{2+}$ was co-precipitated. According to its 


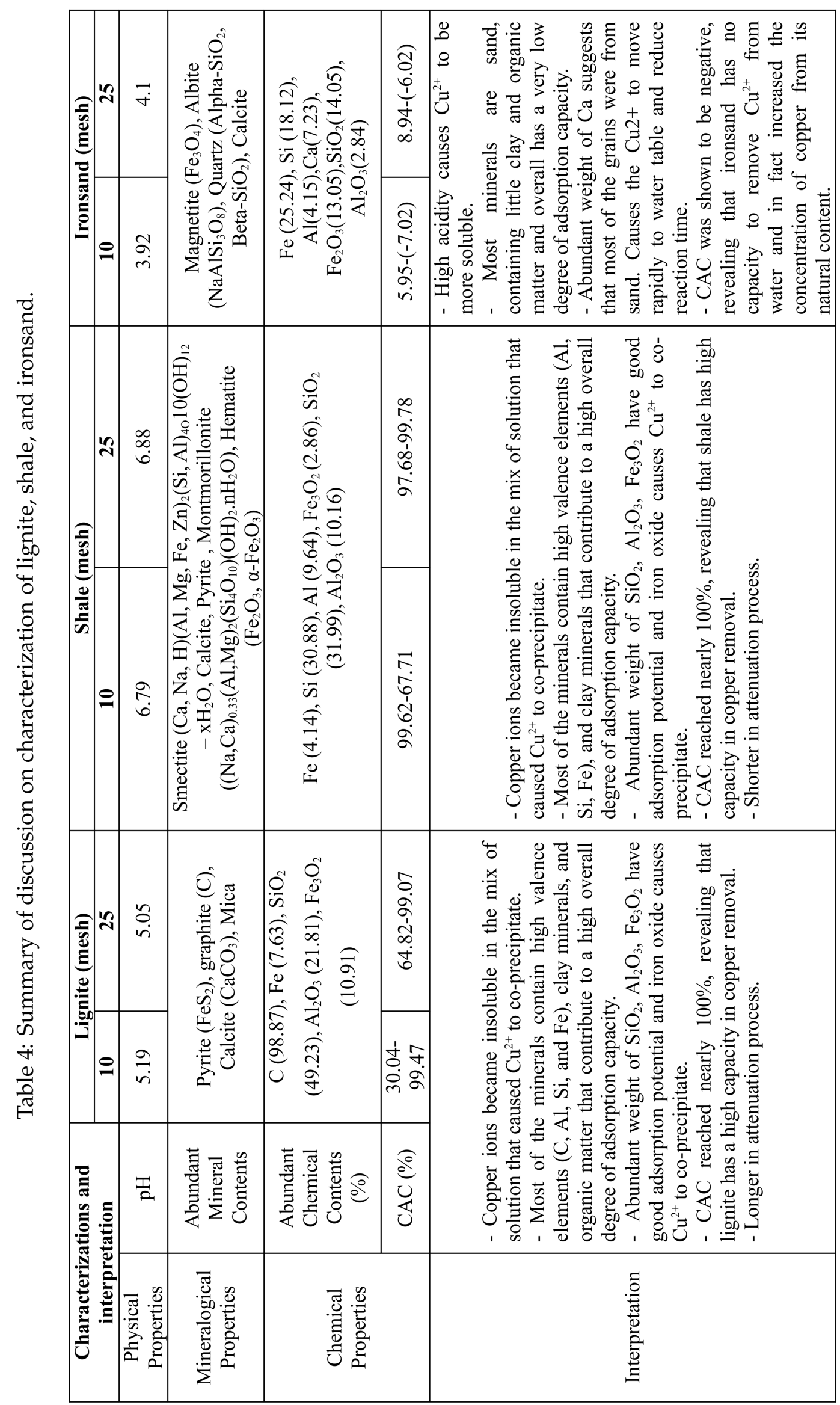




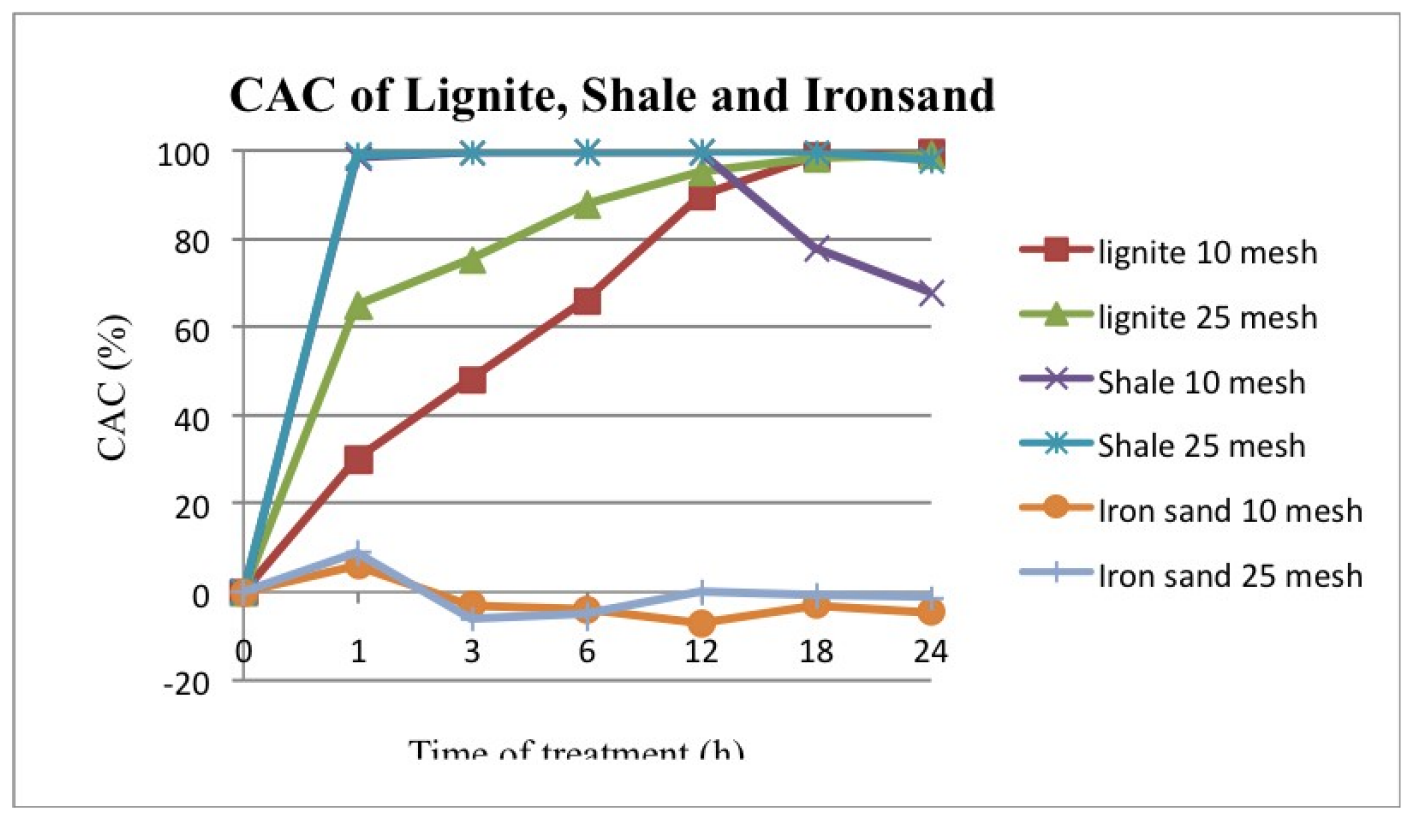

Figure 5: Copper adsorbed by lignite, shale and ironsand.

characteristic study, lignite has a high adsorption capacity and this was further suggested by the column experiment in which CAC treated by lignite reached to $99.47 \%$. When the copper solution was treated by shale, the increasing of $\mathrm{pH}$ to neutral caused $\mathrm{Cu}^{2+}$ to be coprecipitated. From AAS analyses, CAC reached to nearly $100 \%$ and agreeing with the characteristic studies of shale, it suggested that it has a high degree in adsorption capacity. When the copper solution was treated by ironsand, high acidity caused $\mathrm{Cu}^{2+}$ to be more soluble. Ironsand's characteristic studies suggested that it would have a very low ability in adsorption capacity, and the negative value of CAC suggested clearly that ironsand has no ability in adsorption capacity to remove $\mathrm{Cu}^{2+}$ from the solution, and increases the $\mathrm{Cu}^{2+}$ concentration from the natural conditions. Through our experimental studies, it has been suggested that the best material for copper removal in contaminated water is lignite with 25 -mesh grain size.

\section{Acknowledgment}

The writer would like thank to the Indonesian Government, who have encouraged and supported the budget for this Master's Thesis and publication. Special acknowledgement is made to friends and colleagues, who have helped, contributed data, given valuable discussion and suggestions during the preparation of this publication.

\section{References}

Alloway, B.J., and Ayres D.C. (1993) Chemical Principle of Environmental Pollution. By the Alden Press, Oxford ISBN 0-751400130, p. 116-140.

Batchelor, B., Hapka, M., Igwe, G., Jensen, R., McDevitt, M., Schultz, D., and Whang, J. (2002) Method for Remediating Contaminated Soils. United States Patent No. 6,492,572 B2. p. 17-23.

Freethey, G.W., Naftz, D.L., Rowland, R.C. and Davis, J.A. (2002) Deep Aquifer Remediation Tools: theory design and performance monitoring. Elsevier, San Diego, 539p.

Vega, J.L., Ayala, J., Loredo, J., and Garcia, I. J. (2005) Bentonite as Adsorbent of Heavy Metals Ions from Mine Waste Leachates: Experimental Data. 9th International Mine Water Association Congress (IMWAC), Oviedo, Spain, p. 603-609. 